\title{
Microbiological Properties of Apple Orchard (Red Delicious) Soils of Ganderbal District
}

\author{
Baseerat Binti Nabi*, Subhash Chand, M. A. Dar and Khushboo Farooq
}

Division of Soil Science, Sher-e-Kashmir University of Agricultural Sciences and Technology, Shalimar Srinagar, India

*Corresponding author

\begin{abstract}
A B S T R A C T
Keywords

Apple orchard, Apple growing soils

Article Info

Accepted:

18 November 2020

Available Online:

10 December 2020

To study the "Nutrient status of apple growing soils of Ganderbal" soil samples were collected from 21 apple orchards at different locations at three altitudes viz. high, medium and low. The soil samples collected were taken from four depths viz. 0-25, 25-50, 50-75 and 75-100 cm respectively. The soil samples collected were analyzed for various biological parameters were worked out viz. bacteria, fungi and actinomycetes. The range of bacteria, fungi and actinomycetes ranged from 57.12 to $75.7910^{6} \mathrm{cfu} / \mathrm{g}$ soil, 44.13 to $55.3910^{5} \mathrm{cfu} / \mathrm{g}$ soil and 16.99 to $25.7210^{4} \mathrm{cfu} / \mathrm{g}$ soil respectively.

\section{Introduction}

Apple is found in temperate regions of the world at an altitude ranging from 1350 to 2600 meters above mean sea level with an annual rainfall of 125-175 $\mathrm{cm}$. Apple has a diverse climatic adaptation and most of the apple varieties require about 1500 hours of chilling below $7^{0} \mathrm{C}$ to break the rest period. Due to its chilling requirements, it grows best in relatively cooler climates than other deciduous fruits (Westwood and Chestnut, 1964). The average temperature should be around 21 to $24^{\circ} \mathrm{C}$ during the growing season. Apples endure quite low temperatures, but temperatures of $-30^{\circ} \mathrm{C}$ and rapid fluctuation in winter from relatively warm to extremely cold

temperatures are harmful (Bokhari, 2002). For the sustenance of agricultural growth we have to rely on health concept. Soil health is defined as the continued capacity of soil to function as a vital living system, by recognising that it contains biological elements that are key to ecosystem function within land use boundaries (Doran and Zeiss, 2000). Soil health indicators are quite essential for the assessment of soil sustainability. Most of the soil biological activity is confined to surface soils whose depth varies from few to $30 \mathrm{~cm}$. the biological components consist of many soil microorganisms. Irrespective of the small volume of these micro-organisms in soil they play a huge role in the cycling of various nutrients
\end{abstract}


viz. nitrogen, sulphur, phosphorus and also are responsible for the decomposition of organic residues. Micro-organisms quickly respond to environmental stress as compared to higher organisms, as such any change in microbial population can detect changes easily in the soil properties viz. physical and chemical thereby indicating early sign of either soil improvement or degradation. Hence, keeping in view the importance of soil micro-organisms the present study was carried out in Ganderbal district.

\section{Materials and Methods}

Soil samples after collection were air dried, crushed, and sieved through $2 \mathrm{~mm}$ sieve. The processed soil samples were then labeled and stored in cloth bags for analysis of various biological parameters. Following media were used for isolation of different groups of microorganisms. Composition of media (Atlas, 1995) used for study are as follows:

Nutrient agar for bacteria

\begin{tabular}{|c|c|}
\hline Constituents & Quantity/litre \\
\hline Beef extract & $1.5 \mathrm{~g}$ \\
\hline Peptone & $5.0 \mathrm{~g}$ \\
\hline NaCl & $5.0 \mathrm{~g}$ \\
\hline Agar-agar & $15.0 \mathrm{~g}$ \\
\hline Distilled water & $1000 \mathrm{ml}$ \\
\hline
\end{tabular}

Potato Dextrose agar for fungi

\begin{tabular}{|c|c|}
\hline Constituents & Quantity/litre \\
\hline Pealed potato & $250 \mathrm{~g}$ \\
\hline Dextrose & $20 \mathrm{~g}$ \\
\hline Agar-agar & $20 \mathrm{~g}$ \\
\hline Distilled water & $1000 \mathrm{ml}$ \\
\hline
\end{tabular}

Ken Knight and Munaires medium for Actinomycetes

\begin{tabular}{|c|c|}
\hline $\mathbf{K}_{\mathbf{2}} \mathrm{HPO}_{\mathbf{4}}$ & $\mathbf{1 . 0} \mathrm{g}$ \\
\hline $\mathrm{NaNO}_{\mathbf{3}}$ & $0.1 \mathrm{~g}$ \\
\hline $\mathrm{KCl}$ & $0.1 \mathrm{~g}$ \\
\hline MgSO$_{4}$ & $0.1 \mathrm{~g}$ \\
\hline Glucose & $1.0 \mathrm{~g}$ \\
\hline Agar-agar & $15-20 \mathrm{~g}$ \\
\hline Distilled water & $1000 \mathrm{ml}$ \\
\hline
\end{tabular}

\section{Sterilization}

Glasswares used were thoroughly washed in detergent water, running tap water followed by rinsing in distilled water. Glasswares were sterilized in hot air oven at $180^{\circ} \mathrm{C}$ temperature for 30 minutes. All the media, water blanks etc. were sterilized in autoclave at $15 \mathrm{lbs}$ per square inch pressure of pure steam for 20 minutes, unless mentioned otherwise. 
Laminar airflow chamber was sterilized by disinfectant followed by ultra violet (UV) irradiation for 30 minutes before start of the work.

\section{Isolation and enumeration of rhizospheric microorganisms}

\section{Isolation of bacteria}

One gram of the rhizosphere soil was placed in $9 \mathrm{ml}$ of sterilized distilled water under aseptic conditions. Serial dilution of $10^{2}, 10^{3}$, $10^{4}, 10^{5}, 10^{6}, 10^{7}$ were prepared. One $\mathrm{ml}$ of aliquot from specific dilution was added over cooled and solidified nutrient media (NA) in petriplates. The plates were rotated for uniform distribution. The plates were incubated at $28 \pm 2^{\circ} \mathrm{C}$ for 3-4 days. The bacterial colonies were identified on the basis of colony features and morphological characters of cells. The bacterial count was expressed as colony forming unit per gram of soil (Cfu/g soil).

\section{Isolation of fungi}

One gram of rhizosphere soil was placed in 9 $\mathrm{ml}$ of sterilized distilled water under aseptic conditions. Serial dilution of $10^{2}, 10^{3}, 10^{4}, 10^{5}$ were prepared. One $\mathrm{ml}$ of aliquot from specific dilution was added over cooled and solidified potato dextrose agar media in petriplates. The plates were rotated for uniform distribution. The plates were incubated at $28 \pm 2^{\circ} \mathrm{C}$ for $3-4$ days. The fungal colonies were identified on the basis of colony features and morphological characters of cells. The fungal count was expressed as colony forming unit per gram of soil $(\mathrm{Cfu} / \mathrm{g}$ soil).

\section{Isolation of actinomycetes}

One gram of rhizosphere soil was placed in 9 $\mathrm{ml}$ of sterilized distilled water under aseptic conditions. Serial dilution of $10^{2}, 10^{3}, 10^{4}$ were prepared. One $\mathrm{ml}$ of aliquot from specific dilution was added over cooled and solidified ken nights media in petriplates.

The plates were rotated for uniform distribution. The plates were incubated at $28 \pm 2^{\circ} \mathrm{C}$ for $3-4$ days. The actinomycetes colonies were identified on the basis of colony features and morphological characters of cells. The actinomycetes count was expressed as colony forming unit per gram of soil (Cfu/g soil).

\section{Results and Discussion}

\section{Bacteria}

Examination of data in Table 1 revealed that the bacteria content in the surface soils of high, mid and low altitudes varied from 68.11 to $75.79,58.58$ to 72.93 and 59.04 to 70.11 $\mathrm{cfu} / \mathrm{g}$ soil with the mean values of 71.11 , 64.15 and $63.66 \mathrm{cfu} / \mathrm{g}$ soil, respectively. Whereas, in sub-surface soils the content of bacteria in high, mid and low altitudes varied from 67.96 to $71.93,58.31$ to 64.36 and 57.12 to $63.84 \mathrm{cfu} / \mathrm{g}$ soil with the mean values of $69.58,60.92$ and $59.90 \mathrm{cfu} / \mathrm{g}$ soil respectively. Highest bacterial population was found in high altitude and it revealed a decreasing trend with the increase in soil depth.

\section{Fungi}

Representation of data in Table 1 reported that the fungi content of surface soil of apple orchards in high, mid and low altitudes varied from 50.38 to $55.39,47.65$ to 53.29 and 44.74 to $52.60 \mathrm{cfu} / \mathrm{g}$ soils with the mean values of $52.47,49.87$ and $47.87 \mathrm{cfu} / \mathrm{g}$ soil, respectively. Whereas, in sub-surface soils it varied from 48.55 to $51.73,45.80$ to 48.95 and 44.13 to $48.16 \mathrm{cfu} / \mathrm{g}$ soil with the mean values of $49.92,47.18$ and $45.85 \mathrm{cfu} / \mathrm{g}$ soil in high, mid and low altitudes, respectively. 
Highest fungal population was found in high altitude and it revealed a decreasing trend with the increase in soil depth.

\section{Actinomycetes}

Perusal of data in Table 1 showed that the actinomycetes content in surface soils of high, mid and low altitudes varied from 20.85 to $25.72,18.43$ to 22.55 and 17.85 to $22.08 \mathrm{cfu} / \mathrm{g}$ soil with the mean values of 22.67, 20.38 and
$19.35 \mathrm{cfu} / \mathrm{g}$ soil, respectively. Whileas, in sub-surface soils of high, mid and low altitudes it varied from 19.47 to $21.62,17.94$ to 19.90 and 16.99 to $18.88 \mathrm{cfu} / \mathrm{g}$ soil with the mean values of $20.29,18.74$ and $17.71 \mathrm{cfu} / \mathrm{g}$ soil, respectively. Higher actinomycetes population was observed in high altitude soils followed by mid and low altitudes soils whereas, it revealed a decreasing trend with the increase in soil depth.

Table.1 Biological health status of apple orchard soils of Ganderbal

\begin{tabular}{|c|c|c|c|c|}
\hline Orchard Number & $\begin{array}{l}\text { Depth } \\
\text { (cm) }\end{array}$ & $\begin{array}{c}\text { Bacteria } \\
\left(10^{6} \mathrm{cfu} / \mathrm{g} \text { soil }\right)\end{array}$ & $\begin{array}{c}\text { Fungi } \\
\left(10^{5} \mathrm{cfu} / \mathrm{g} \text { soil }\right)\end{array}$ & $\begin{array}{l}\text { Actinomycetes } \\
\left(10^{4} \text { cfu/g soil }\right)\end{array}$ \\
\hline 1 & 2 & 3 & 4 & 5 \\
\hline \multicolumn{5}{|c|}{ HIGH ALTITUDE } \\
\hline \multirow[t]{4}{*}{ H-1 } & $0-25$ & 77.02 & 55.41 & 26.98 \\
\hline & $25-50$ & 77.19 & 54.56 & 25.74 \\
\hline & $50-75$ & 76.04 & 53.12 & 24.13 \\
\hline & $75-100$ & 75.39 & 52.89 & 22.40 \\
\hline \multirow[t]{4}{*}{ H-2 } & $0-25$ & 76.48 & 52.90 & 22.86 \\
\hline & $25-50$ & 75.02 & 51.22 & 21.02 \\
\hline & $50-75$ & 74.12 & 50.08 & 20.06 \\
\hline & $75-100$ & 73.92 & 50.00 & 19.86 \\
\hline \multirow[t]{4}{*}{ H-3 } & $0-25$ & 74.42 & 56.63 & 19.93 \\
\hline & $25-50$ & 73.51 & 55.89 & 18.41 \\
\hline & $50-75$ & 72.10 & 54.33 & 18.23 \\
\hline & $75-100$ & 70.19 & 52.58 & 16.31 \\
\hline \multirow[t]{4}{*}{ H-4 } & $0-25$ & 70.51 & 51.43 & 20.73 \\
\hline & $25-50$ & 69.32 & 50.91 & 19.88 \\
\hline & $50-75$ & 68.81 & 49.06 & 18.61 \\
\hline & $75-100$ & 67.42 & 48.01 & 17.02 \\
\hline \multirow[t]{4}{*}{ H-5 } & $0-25$ & 69.11 & 54.28 & 21.98 \\
\hline & $25-50$ & 68.20 & 53.19 & 20.27 \\
\hline & $50-75$ & 67.90 & 51.36 & 19.45 \\
\hline & $75-100$ & 65.14 & 49.96 & 18.62 \\
\hline \multirow[t]{4}{*}{ H-6 } & $0-25$ & 65.72 & 49.42 & 24.82 \\
\hline & $25-50$ & 64.18 & 47.11 & 23.19 \\
\hline & $50-75$ & 63.13 & 45.06 & 22.01 \\
\hline & $75-100$ & 62.42 & 42.01 & 20.06 \\
\hline \multirow[t]{4}{*}{ H-7 } & $0-25$ & 70.42 & 50.16 & 25.72 \\
\hline & $25-50$ & 69.38 & 48.94 & 23.12 \\
\hline & $50-75$ & 68.34 & 47.63 & 21.81 \\
\hline & $75-100$ & 67.25 & 45.11 & 21.40 \\
\hline Surface Mean & & 71.11 & 52.47 & 22.67 \\
\hline $95 \%$ CI & & 68.11-75.79 & 50.38-55.39 & $20.85-25.72$ \\
\hline Subsurface Mean & & 69.58 & 49.92 & 20.29 \\
\hline $95 \%$ CI & & 67.96-71.93 & $48.55-51.73$ & 19.47-21.62 \\
\hline
\end{tabular}




\begin{tabular}{|c|c|c|c|c|}
\hline 1 & 2 & 3 & 4 & 5 \\
\hline \multicolumn{5}{|c|}{ MID ALTITUDE } \\
\hline \multirow[t]{4}{*}{ M-1 } & $0-25$ & 75.41 & 54.12 & 21.12 \\
\hline & $25-50$ & 69.54 & 51.32 & 22.43 \\
\hline & $50-75$ & 69.02 & 47.52 & 19.81 \\
\hline & $75-100$ & 67.11 & 42.31 & 17.89 \\
\hline \multirow[t]{4}{*}{ M-2 } & $0-25$ & 69.42 & 49.21 & 21.41 \\
\hline & $25-50$ & 69.44 & 48.12 & 20.43 \\
\hline & $50-75$ & 69.08 & 45.91 & 19.11 \\
\hline & $75-100$ & 67.01 & 42.51 & 19.02 \\
\hline \multirow[t]{4}{*}{ M-3 } & $0-25$ & 71.12 & 52.24 & 17.43 \\
\hline & $25-50$ & 67.45 & 51.69 & 17.10 \\
\hline & $50-75$ & 65.34 & 51.54 & 16.91 \\
\hline & $75-100$ & 65.10 & 49.03 & 15.12 \\
\hline \multirow[t]{4}{*}{ M-4 } & $0-25$ & 54.12 & 48.73 & 19.42 \\
\hline & $25-50$ & 58.29 & 47.12 & 18.12 \\
\hline & $50-75$ & 57.45 & 45.43 & 17.21 \\
\hline & $75-100$ & 54.32 & 45.10 & 17.11 \\
\hline \multirow[t]{4}{*}{ M-5 } & $0-25$ & 59.42 & 50.21 & 23.02 \\
\hline & $25-50$ & 60.98 & 50.01 & 22.11 \\
\hline & $50-75$ & 60.15 & 48.31 & 21.42 \\
\hline & $75-100$ & 57.19 & 47.21 & 20.19 \\
\hline \multirow[t]{4}{*}{ M-6 } & $0-25$ & 60.42 & 53.45 & 22.93 \\
\hline & $25-50$ & 52.11 & 53.02 & 21.45 \\
\hline & $50-75$ & 51.02 & 51.03 & 21.03 \\
\hline & $75-100$ & 47.15 & 49.53 & 20.63 \\
\hline \multirow[t]{4}{*}{ M-7 } & $0-25$ & 70.43 & 45.39 & 18.11 \\
\hline & $25-50$ & 62.11 & 44.19 & 17.71 \\
\hline & $50-75$ & 60.10 & 42.11 & 16.42 \\
\hline & $75-100$ & 58.11 & 42.01 & 16.17 \\
\hline Surface Mean & & 64.15 & 49.87 & 20.38 \\
\hline $95 \%$ CI & & 58.58-72.93 & 47.65-53.29 & $18.43-22.55$ \\
\hline Subsurface Mean & & 60.92 & 47.18 & 18.74 \\
\hline $95 \% \mathrm{CI}$ & & $58.31-64.36$ & $45.80-48.95$ & $17.94-19.90$ \\
\hline
\end{tabular}

\begin{tabular}{|c|c|c|c|c|}
\hline $\mathbf{1}$ & 2 & 3 & 4 & 5 \\
\hline \multicolumn{5}{|c|}{ LOW ALTITUDE } \\
\hline \multirow[t]{4}{*}{ L-1 } & $0-25$ & 70.12 & 53.45 & 23.69 \\
\hline & $25-50$ & 71.21 & 52.18 & 22.38 \\
\hline & $50-75$ & 68.43 & 51.09 & 21.24 \\
\hline & $75-100$ & 63.21 & 50.14 & 21.03 \\
\hline \multirow[t]{4}{*}{ L-2 } & $0-25$ & 71.32 & 50.32 & 19.45 \\
\hline & $25-50$ & 67.12 & 49.17 & 18.63 \\
\hline & $50-75$ & 64.32 & 48.62 & 18.89 \\
\hline & $75-100$ & 60.12 & 45.16 & 17.45 \\
\hline \multirow[t]{4}{*}{ L-3 } & $0-25$ & 68.83 & 51.02 & 18.89 \\
\hline & $25-50$ & 68.21 & 50.45 & 17.73 \\
\hline & $50-75$ & 65.12 & 49.32 & 17.43 \\
\hline & $75-100$ & 63.10 & 48.73 & 15.29 \\
\hline \multirow[t]{2}{*}{ L-4 } & $0-25$ & 59.19 & 46.01 & 17.43 \\
\hline & $25-50$ & 51.42 & 45.39 & 16.38 \\
\hline
\end{tabular}




\begin{tabular}{|c|c|c|c|c|}
\hline & $50-75$ & 48.32 & 44.55 & 15.12 \\
\hline & $75-100$ & 47.12 & 41.02 & 15.01 \\
\hline \multirow{4}{*}{ L-5 } & $0-25$ & 61.13 & 45.08 & 20.93 \\
\hline & $25-50$ & 57.12 & 44.18 & 20.01 \\
\hline & $50-75$ & 56.01 & 43.02 & 18.43 \\
\hline & $75-100$ & 53.51 & 41.89 & 17.90 \\
\hline \multirow[t]{4}{*}{ L-6 } & $0-25$ & 55.73 & 52.62 & 21.77 \\
\hline & $25-50$ & 57.41 & 50.43 & 19.26 \\
\hline & $50-75$ & 54.42 & 49.86 & 18.52 \\
\hline & $75-100$ & 52.25 & 47.62 & 18.03 \\
\hline \multirow[t]{4}{*}{ L-7 } & $0-25$ & 65.77 & 42.21 & 17.64 \\
\hline & $25-50$ & 69.49 & 40.33 & 16.52 \\
\hline & $50-75$ & 65.93 & 39.05 & 16.02 \\
\hline & $75-100$ & 65.43 & 36.99 & 15.48 \\
\hline Surface Mean & & 63.66 & 47.87 & 19.35 \\
\hline $95 \% \mathrm{CI}$ & & $59.04-70.11$ & $44.74-52.60$ & $17.85-22.08$ \\
\hline Subsurface Mean & & 59.90 & 45.85 & 17.71 \\
\hline $95 \%$ CI & & $57.12-63.84$ & 44.13-48.16 & $16.99-18.88$ \\
\hline Overall Surface Mean & & 67.43 & 50.68 & 21.25 \\
\hline $95 \% \mathrm{CI}$ & & $64.38-70.48$ & 49.00-52.35 & $20.01-22.48$ \\
\hline $\begin{array}{c}\text { Overall Subsurface } \\
\text { Mean }\end{array}$ & & 63.90 & 47.89 & 19.13 \\
\hline $95 \%$ CI & & $62.01-65.79$ & 46.85-48.92 & $18.52-19.74$ \\
\hline
\end{tabular}

Highest bacterial population was found in soils of high altitude and it revealed a decreasing trend with the increase in soil depth, this may be attributed to the high content of organic carbon and may also be due to presence of various nutrients in the soil especially the soil nitrogen and sulphur in the soil. The bacterial population may also increase due to application of inorganic fertilizers in the soil. The soil bacterial population may also vary due to natural vegetation and the moisture in soil (Bashir, 2015). Highest fungal population was found in high altitude soils and it revealed a decreasing trend with the increase in soil depth, which may be due to more organic matter which serves as the chief source of energy and food for most of the soil organisms as it has a great influence on microbial population. Organic matter influences directly or indirectly the population and activity of soil micro-organisms. The increase in natural vegetation also increases the fungal population (Bashir, 2015). Higher actinomycetes population was observed in high altitude soils followed by mid and low altitudes soils whereas, it revealed a decreasing trend with the increase in soil depth, which may be due to various factors like variation in organic matter, salinity, relative moisture, temperature, $\mathrm{pH}$ and vegetation which control abundance of actinomycetes in soil (McCarthy and Williams, 1992) and Bashir (2015).

\section{References}

Atlas, R.M. 1995. Handbook Media for Environmental Microbiology. CRL, Press Bocaratar, New York, pp. 43371.

Bashir, O. 2015. Biological health status of apple growing soils of Baramulla District of Kashmir Valley. M.Sc. thesis submitted to SKAUST-Kashmir., pp. 120.

Bokhari, S. 2002. Apple the sweet gold of Pakistan. Export Promotion Bureau of Pakistan 5: 2-15.

Doran, J. and Zeiss, M. 2000. Soil health and 
sustainability: Managing the biotic component of soil quality. Applied Soil Ecology 15: 3-11.

McCarthy, A.J. and Williams, S.T. 1992. Actinomycetes as agents of biodegradation in the environment- a review. Gene 115: 189-192.
Westwood, M. N. and Chestnut, N. E. 1964. Rest period chilling requirements of Bartlett pear as related to Pyrus calleryana and $P$. communis rootstocks. Proceedings American Society Horticultural Science 84: 82-87.

\section{How to cite this article:}

Baseerat Binti Nabi, Subhash Chand, M. A. Dar and Khushboo Farooq. 2020. Microbiological Properties of Apple Orchard (Red Delicious) Soils of Ganderbal District. Int.J.Curr.Microbiol.App.Sci. 9(12): 2817-2823. doi: https://doi.org/10.20546/ijcmas.2020.912.336 